\title{
AIKUISKASVATUS JA BRECHTIN
}

OHJE

\author{
"Opi perusasiat", kiteytti Bertold Brecht Oppimisen ylistyksessään edel- \\ leen pätevän pedagogisen ohjeen. Pelkäämme, että kasvatustieteissä \\ perusteiden oppiminen on unohtunut muodikkaiden työelämälähtöisyyden \\ ja laaturetoriikan alle. Tämä pätee nähdäksemme sekä metodisen osaa- \\ misen että tieteenalaa rakentavien peruskäsitteiden, teoriaperinteiden ja \\ arvojen alueella. Perusasioiden tuntemattomuus heijastuu teoriallisen \\ ohuuden ohella myös empiiristen tutkimusten kysymyksenasettelujen \\ mielekkyyteen. Hyvin perusteltujen teorioiden avulla luotu kuva \\ tarkasteltavasta ilmiökentästä tarjoaa kuitenkin aina mahdollisuuden \\ tulkita ilmiötä myös uudella, kiinnostavalla tavalla.
}

TOMI KIILAKOSKI

$\mathrm{T}$ 7uoreen tohtorin Sari Poikelan Aikuiskasvatus-lehden numerossa 3/2003 julkaistu lectio heijastelee kasvatustieteissä yleistynyttä yliolkaista tapaa suhtautua oman tieteenalan historiaan. Lection merkitys akateemisen oppineisuuden osoittamisen topoksena saa kiinnittämään huomiota tekstissä esiintyviin väittämiin. Poikelan lectiossa on joitakin yliolkaisia väitteitä tieteen perusmekanismeista, joiden tunteminen kuuluu nähdäksemme jokaisen akateemisen tutkinnon suorittaneen yleissivistykseen. Ne ovat siis paraatiesimerkki Brechtin tarkoittamista perusasioista.

Poikela kirjoittaa lectiossaan deduktion ja induktion olevan modernismin tuotteita. Sama väittämä toistuu hänen väitöskirjassaan. Siinä tosin viittauksena on R.S.Prawatin kirjoittama artikkeli Dewey, Peirce and the Learning Paradox, joka muodostaa Poikelalle tiuhaan viitatun päälähteen induktion, deduktion ja abduktion käsittelylle. Väite on perätön, mikä on selvä jokaiselle länsimaista aatehistoriaa tuntevalle. Deduktiivinen päättely oli tuttu jo antiikin kreikkalaisille. Ensimmäiset kirjallisessa muodossa tätä päättelyn muotoa käsittelevät säilyneet tekstit ovat Aristoteleen teoksissa. Deduktio formaalin päättelyn muotona on siis perintöä esimodernilta ajalta. Deduktiivista logiikkaa on myös hankala olla noudattamatta, mikäli aikoo päätellä ymmärrettävästi.
Poikelan väite, että deduktio ja induktio edellyttävät jaon mielen ja maailman välillä, on ongelmallinen. Induktion käsittely modernin ajattelun piirissä on toki usein liittynyt subjektifilosofiaan, mutta sellaisenaan väite on turhan yleistävä. Samoin epäselvää on, miksi Poikela mainitsee myös näiden termien englanninkieliset vastineet. Jo kreikkalaiset tuntevat

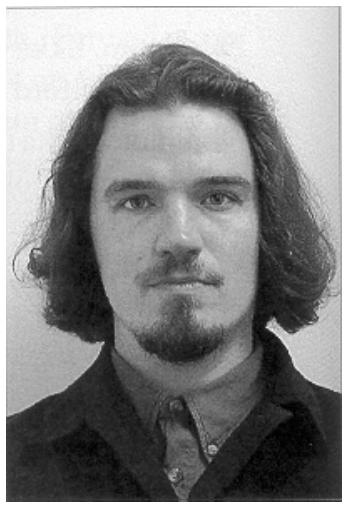

Tomi Kiilakoski deduktion. Yleisesti viitatuimpia induktion esittelyjä modernilla ajalla lienee Francis Baconin Novum Organum, jonka tarkoitus oli korvata Aristoteleen syllogistinen logiikka uudella induktion menetelmällä. Baconin teos on kirjoitettu latinaksi. Baconin induktiokäsityksen erheenä on pidetty, että Bacon oletti induktion avulla tiedon sellaisenaan kumpuavan havainnosta eikä hän tunnistanut tieteen tekemisen muita mekanismeja.

Kummallisimpia kohtia Poikelan tekstissä lienee lause: "Peirce käytti 1950-luvulla juuri abduktiota kuvatessaan käsitysten syntyä..." (Aikuiskasvatus 3/2003, s. 220.). Poikelan väitöskirjassa viitataan Peircen 1955 julkaistuun kokoelmateok- 
seen. Peirce kuitenkin eli vuosina 1839-1914. Suomalaisella lukijalla on mahdollisuus tutkia Peircen elinaikanaan kirjoittamia tekstejä Markus Långin valikoimassa ja suomentamassa kokoomateoksessa Johdatus tieteen logiikkaan ja muita kirjoituksia (Vastapaino, 2001). Mikäli väittämä olisi ainoa historiallisesti kyseenalainen seikka, voitaisiin se varmaankin sivuuttaa. Yhdessä muiden epämääräisten väittämien kanssa se pakottaa pohtimaan kasvatustieteen historian tuntemisen tai paremminkin tuntemattomuuden merkitystä.

Poikelan abduktion kuvailu vaikuttaa omituiselta. Peircestä Poikelan tavoin kirjoittanut Ilkka Niiniluoto määrittelee abduktion kirjassaan Tieteellinen päättely ja selittäminen (Otava, 1983) . Niiniluoto tulkitsee abduktiivisen päättelyn etenevän jostakin tunnetusta tosiseikasta tätä tosiseikkaa parhaimmalla tavalla selittävään hypoteesiin.

i. Yllättävä tosiseikka e on todettu.

ii. e ei olisi yllättävä mikäli hypoteesi h olisi tosi.

iii. Siis on perusteita olettaa h:n olevan tosi. (Niiniluoto 1983, 154.)

Abduktio siis etenee Peircen mukaan yksittäisestä yleiseen. Kutakin ilmiötä selittämään pyritään löytämään sopiva hypoteesi. Kriittisestä näkökulmasta voidaan huomauttaa, ettei peirceläinen abduktio välttämättä eroa hypoteettisdeduktiivisestä tieteestä, koska siinä selittävä hypoteesi h on oletettu premisseissä.

Peirce ei luonnollisestikaan oleta, että hypoteesien esittäminen tapahtuisi suoraviivaisesti hatusta temmaten, vaan se pohjautuu aiempaan tietomäärään ja tieteen tuntemukseen. Markus Långin suomennoksessa abduktiosta käytetään termiä 'hypoteesi'. Långin terminologinen valinta korostaa tulkintaa, jossa Peircen abduktio nähdään yhtenä mahdollisuutena esittää yleisiä hypoteeseja, eikä suinkaan jonkin oppimisen malliparadigman näennäistieteellisenä varmentajana.

Poikelan Peircen käsittelyn ongelma siis on, että osa yleisestä ja institutionaalisesta tieteen tiedonhankinnan perusmekanismista irrotetaan erikseen (Peircellä abduktio esiintyy yhdessä deduktion ja induktion kanssa) ja nähdään myös yksittäisen ihmisen oppimisprosessin kuvauksena. Myös Deweyn monisyinen teoretisointi tulee käsitellyksi yksilöpsykologisen kehyksen näkökulmasta, huolimatta siitä että Dewey itse näki itsensä liberalistisen yksilökäsityksen tiukkana ja ehdottomana kriitikkona.

Oman tieteenalan perusteiden tunteminen on luonnollisesti hankala tehtävä. Klassikoiden lukemiseen tulee varata paljon aikaa - yhden tai muutaman PBL-syklin mittainen aika ei missään nimessä riitä syvälliseen oppimiseen. Kenties juuri pinnallisuuteen muutoinkin viettelevän postmodernin aikakautena olisi hyvä perehtyä omien tutkimuspyrintöjen teoriahistorioihin. "Isojen kuvien" laiminlyöntien seuraukset saattavat näkyä esimerkiksi siten, että yhteiskunta redusoituu työelämän tarpeisiin tai ns. osaamiseen, jolloin opetus- ja kasvatustapahtuman kompleksinen luonne litistetään vain yhden menetelmän tai ajattelumallin mankeliin. Yleisimmin tutkimuspolitiikka ja yliopistojen toiminta saattaa kaveta ulkopuolisen rahoituksen perässä juoksevaksi konsulttitoiminnaksi, jonka tärkein tehtävä on tuottaa työelämän nykytoiveita myötäileviä tutkimuksen nimellä kulkevia selvityksiä.

Postmodernina, epävarmana aikana juuri historian tuntemus korostuu. Kasvatustieteiden nykyinen teoreettinen kapeutuminen näyttäytyy meille uhkana. Epävarmuuteen reagoiminen edellyttää kykyä nojautua useisiin eri teoriaperinteisiin - niitä parhaan mukaan tuntien ja tulkiten sekä kykyä suunnistaa näiden perinteiden varassa tulevaisuuteen omaan tutkijan näkemykseensä luottaen. Perusteiden tunteminen on vain lähtökohta, mutta tarpeellinen sellainen. "Se ei riitä, mutta opi ne."

JÄLKISANAT: Saamastani tuesta ja kriittisistä kommenteista kiitän seuraavia henkilöitä: lehtori Tero Autio, lehtori Jorma Lehtovaara, tutkija Tommi Vehkavaara, professori Veli-Matti Värri. 